\title{
O Teatro hip-hop como linguagem e alguns de seus pontos fundamentais
}

Foi a partir do vislumbre de uma contracena de linguagens que no ano de 1999 a atriz, figurinista, dramaturga e diretora Claudia Schapira deu início à realização do projeto do espetáculo Bartolomeu, o que será que nele deu?, inspirado em Bartleby, the Scrivener: A Story of Wall Street (1953), do escritor americano Herman Melville. Esse espetáculo, que estreou em dezembro de 2000, foi a primeira experiência do que se tornaria mais tarde o Núcleo Bartolomeu de Depoimentos e do que seria sua linguagem - o Teatro hip-hop.

Bartolomeu, o que será que nele deu? conta a história de um homem comum, cidadão urbano, que corre contra o tempo, mas que um dia resolve parar com todas as suas atividades e fica paralisado diante da velocidade e do caos iminente da cidade, que ele sente ser impossível de alcançar e conviver. As temáticas da cidade e do homem frente a seus mecanismos foram focos de interesse desse projeto, bem como a busca de um ritmo e uma pulsação específicos que dessem conta de expressá-los.

A inquietação com os desafios e dialéticas da vida urbana e a pesquisa de seus temas já tinham se materializado em outro trabalho de Claudia Schapira, em parceria com a atriz Lú Grimaldi: Nocaute - Episódios da Alma Cotidiana (1999, direção de Beth Lopes). O espetáculo se passava num cenário que remetia a um ringue de boxe e evocava situações metafóricas, trazendo o cotidiano massacrante da cidade e a luta pela sobrevivência em meio a suas inoperâncias e belezas. Tanto em traços da linguagem corporal quanto na utilização da música em cena, esse espetáculo já apresentava, ainda que difusamente, alguns dos elementos que se tornariam constitutivos no trabalho que o Núcleo Bartolomeu desenvolveria posteriormente. Mas foi a partir do contato com a companhia de dança de rua "Unidade Móvel" que o que era

\footnotetext{
${ }^{1}$ Companhia de dança de rua criada nos anos 90 pelos dançarinos Eugênio Lima, Mariana Lima e Wil Robson.
} 
um vislumbre de junção de linguagens tomou contornos mais nítidos, como relembra Claudia Schapira²:

Quando eu conheci a Unidade Móvel, parecia que tinha explodido uma bomba dentro da minha retina.(...) me lembro especificamente de um dia que eu vi o grupo pela primeira vez. O espaço Nova Dança estava abrindo, e eles estavam fazendo uma festa no terraço. Eles chamaram a gente pra fazer o Nocaute, e a Unidade Móvel. A coisa acontecia simultaneamente, nós fazendo o Nocaute, a céu aberto no meio do Bexiga, e eles dançando ali do outro lado. O público assistia do meio. A dança deles descrevia, coincidentemente, tudo que a gente estava narrando, ou seja, quando eu olhei aquilo, eu falei: isso é exatamente a expressão física daquilo que eu quero corporificar como um texto e voz em um teatro. Foi assim, foi um insight mesmo. Aquilo revelou alguma uma coisa pra mim que sempre busquei a cada trabalho, as referências físicas que pudessem corporificar os assuntos sobre os quais eu estava falando.

Naquele momento, o hip-hop vinha personificado na dança de rua, e sua percepção como uma potência comunicativa, explosiva e urgente, em conjunto com o teatro, teve seu início prático em março de 2000. Foi nesse período que os representantes da cultura hip-hop e suas manifestações artísticas (DJ, MC, B.Boy, B.Girl e grafiteiro) e os representantes do teatro (atores, dramaturga e diretor) se encontraram na sala de ensaio. Embora alguns já tivessem familiaridade com o hip-hop, os atores começaram a ser introduzidos a pontos mais específicos do universo da cultura das ruas e às particularidades e técnicas de seus quatro elementos ${ }^{3}$. Paralelamente, os integrantes da cultura hip-hop participavam de estudos e práticas da linguagem cênica; e enquanto isso a dramaturgia escrita buscava alcançar um texto contundente, que conseguisse, por meio de seu ritmo e poética, colocar o som das ruas na fala dos atores. O treinamento corporal tinha como foco principal a dança de rua, não exatamente na reprodução literal de seus passos e manobras, mas sim na incorporação de sua pulsação. Essa pulsação, o shuffle, como é denominada no universo da música e da dança de rua, foi um dos elementos de presença mais marcantes no espetáculo, por conta de sua capacidade de traduzir a movimentação e frequência do universo urbano, de uma multidão diversa

2 Entrevista com Claudia Schapira concedida à Roberta Marques do Nascimento em 08/02/2012

${ }^{3}$ DJ Afrika Bambaataa: é considerado mentor intelectual da cultura hip-hop, e em grande parte das fontes escritas e orais é citado como quem a nomeou e a convencionou a partir de seus quatro elementos (embora haja rumores de que o próprio Bambaataa dá esse crédito ao DJ Lovebug Starski). São eles: o MC (master of ceremonies), o mestre de cerimônias, poeta e cronista que por meio da articulação de rimas narra a realidade na qual está inserido. Seus outros três elementos são: o DJ (disc-jockey), que a partir de dois toca-discos torna-se uma espécie de "tutor" do passado fonográfico concreto, contador de histórias musicais, que transforma sua experiência musical individual na vivência do coletivo; o B.boy/ B.girl (break boy /break-girl): dançarino de rua, aquele que dança durante os break-beats, autodidata da criação; o Grafiteiro: artista gráfico das ruas, que utiliza os muros e tem a cidade como moldura para os seus grafites. Traz a transgressão como meio e a arte do aerossol como fim. 
que se desloca em bloco pelas ruas em um pulso comum. Apesar dessa pulsação ter se tornado um ritmo dominante no espetáculo, a dança de rua em si, muito por conta de sua especificidade técnica, não chegou à sua potência de realização pelos atores, sendo necessária a presença de dois dançarinos (B.Boys e B.Girls) que entravam em cena em momentos específicos, referenciando assim a presença deste elemento no palco. Treinamentos de basquete também foram incluídos na preparação dos atores, pois têm alto impacto aeróbico (ou seja, são eficazes na preparação física), e simbolizam um esporte tradicionalmente praticado nas ruas e ligado à cultura hip-hop. Além disso, em seu aspecto de jogo, o basquete revela em suas posições de marcação e deslocamentos uma base para possíveis movimentações cênicas.

É interessante notar que o início desse processo de junção do teatro épico ao hip-hop se deu primeiramente no âmbito do gesto, ou seja, um caminho natural, já que o "teatro épico é um teatro gestual" e "o gesto é seu material, e a aplicação adequada desse material é a sua tarefa"4.

O "gestus social" foi pinçado da realidade e inserido na cena por meio da observação e reprodução de sua frequência de pulsação, usando como interface a dança de rua, que por si só já é também portadora de um gestus social.

Além dos treinamentos e estudos que envolviam diversos profissionais do teatro e do hip-hop, esse trabalho começou a ser dirigido pelo ator e diretor Luciano Chirolli, que a uma certa altura, por motivos profissionais, teve que se desligar do projeto. É importante salientar esse ponto, pois foi justamente na ausência de um diretor, na ânsia de que a pesquisa não se estagnasse e na busca incessante por respostas às inquietações que estavam colocadas, que se criou e se fundamentou todo o método conhecido como "depoimento", que mais tarde daria nome ao Núcleo Bartolomeu de Depoimentos. O depoimento consistia em uma espécie de "roda-viva", um tribunal figurativo onde cada atriz (o elenco era composto de cinco atrizes) personificava um personagem e "defendia" seu ponto de vista. De posse de uma premissa inicial de investigação ("quem era a personagem e qual o papel social que ela representava"), as atrizes se lançavam à procura de seu objetivo. Por meio da observação identificavam aspectos da realidade que interessavam aos seus propósitos e, recortando esses aspectos, estetizando-os e contextualizando-os de acordo com a narrativa da peça, traziam para a arena do depoimento o ponto de vista a

4 BENJAMIN, Walter. Magia e Técnica, Arte e Política: ensaios sobre literatura e obras da cultura. Tradução de Sergio Paulo Rouanet. São Paulo: Brasiliense, 1985. 
ser defendido. Assim eram interpeladas pelos demais que tinham o papel de testá-los por meio de perguntas pra saber até que ponto o discurso era suficientemente forte em forma e conteúdo para a sua sustentação. Os aspectos corporais, vocais, conceituais e ideológicos que compunham o gestus trazido pelas atrizes eram colhidos não só pela observação de campo, mas recortados e sampleados de filmes, livros e referências iconoclásticas. A combinação desses elementos constituía a composição do que seria defendido, algo além de personagens, ou seja, tratava-se de pontos de vista, ou, "brechtianamente" falando, de classes sociais. Durante essa busca, todas as atrizes trouxeram depoimentos de todos os personagens, independente do qual iriam representar. Formou-se então um painel de pontos de vista materializados em formas, palavras e gestus, que foram selecionados e que a partir de um processo-colagem feito pela dramaturgia deram corpo ao discurso de cada uma das personagens, que, justamente pela maneira coletiva pela qual foram criadas, contemplavam o pensamento daquele coletivo sobre elas.

Portanto, o depoimento foi e continua sendo uma célula fundadora do teatro hip-hop. Surgiu a partir dos atores, que na urgência da procura, em um momento ápice de um processo criativo, criaram uma metodologia. Essa metodologia fundante permaneceu como ponto de partida e foi utilizada para encontrar as personagens, as vozes e discursos em todos os processos do Núcleo Bartolomeu, inclusive em seu mais recente espetáculo, Orfeu Mestiço, uma hip-hópera brasileira, em que chegamos ao máximo da linguagem do teatro hip-hop, e do ator-MC como seu fruto.

\section{O Teatro hip-hop e o ator-MC}

Foi ainda durante o processo de ensaios de Bartolomeu, o que será que nele deu?, no ano 2000, que o DJ Eugênio Lima, durante uma viagem a Nova lorque, tomou conhecimento do Hip-hop Theatre Festival, e do termo "teatro hip-hop". Fundado naquele ano por Clyde Valentin, Danny Hoch e Kamilah Forbes, o primeiro Hip-hop Theatre Festival trouxe em um só evento atores, diretores, dramaturgos e dançarinos que representavam a voz da chamada "geração hip-hop". O que poderia ser uma simples nomenclatura, foi o ponto de convergência para diversos artistas que sincronicamente criavam a partir de diferentes linguagens, como afirma Eisa Davis em seu artigo Found in Translation: The Emergence of Hip-hop Theatre ${ }^{5}$ :

5 DAVIS, Eisa. Found in Translation: The Emergence of Hip-hop Theatre, CHANG, Jeff. (org) Total Chaos, the art and aesthetics of hip-hop. New York: Basic Civitas Books, 2006. 
(...) um novo movimento nasceu, uma forma de arte sincrética que, na combinação de dois gêneros, estava realmente revitalizando a estética de cada um. Ter um nome para o que fizemos de repente significava que tínhamos uma comunidade. (...) O nome teatro hip-hop ainda aproxima pessoas que reconhecem que a separação do hip-hop e do teatro já sempre foi uma desnecessária divisão artificial. Teatro hip-hop é uma reunião de família. É o filho do hip-hop com o teatro. Talvez haja um outro nome que ainda possa ser encontrado. Por enquanto, ele leva o nome de seus pais, e é mais do que a soma de suas partes.

Ainda na época da montagem de Bartolomeu, o que será que nele deu? tomou-se conhecimento da existência do teatro hip-hop e houve o imediato reconhecimento de que o trabalho que aqueles artistas estavam desenvolvendo fazia parte dessa "árvore", e logo o termo "teatro hip-hop" começou a ser utilizado pelo grupo que mais tarde se tornaria o Núcleo Bartolomeu de Depoimentos. Assim, o teatro hip-hop foi se formalizando e os conceitos foram surgindo a partir das necessidades de nomear os frutos surgidos da junção das linguagens.

Especificamente no campo da performance poética, da oralidade e do trabalho com a palavra, um conceito central dentro do trabalho deste núcleo de pesquisa é o de ator-MC, artista híbrido que traz na sua gênese as características narrativas do ator épico (o distanciamento, o anti-ilusionismo, o gestus, a determinação do pensar pelo ser social), mixado ao autodidatismo, à contundência e ao estilo inclusor, libertário e veemente do MC, acrônimo para master of ceremonies (mestre de cerimônias). O MC é um dos quatro elementos da cultura hip-hop, que pulsa na contundência do discurso das ruas, na apropriação de quem conhece e conta sua própria história, tornando-se um porta-voz que narra, através de articulações de rimas - o rap (rhythm and poetry ritmo e poesia) - e com um estilo próprio, a realidade na qual está inserido.

Os pontos fundamentais dessa fusão que resulta no ator-MC são a autorrepresentação e o depoimento, que, como estruturas da narrativa, configuram-se como célula fundamental da concepção dramatúrgica e da criação de personagens, discursos e de performances poéticas dentro do Teatro hip-hop. A presença de um ponto de vista claro e a sua defesa, a consciência de seu papel social e político, e o intransferível direito de contar sua própria história e da sociedade na qual está inserido, são características definitivas do ator-MC. O ator-MC é a voz do Teatro hip-hop, um ator-narrador que incorpora os procedimentos estéticos do MC em sua performance, e que, por não trabalhar exclusivamente com as técnicas de atuação do teatro, traz em seu processo criativo e em suas especificidades de linguagem, os procedimentos estéticos e referências históricas da cultura hip-hop, fazendo com que 
os resultados expressivos transitem, se entrecruzem e até mesmo se contraponham entre os campos do teatro e a "cultura das ruas". Portanto, a voz do MC se materializa dentro da performance do ator-MC, afetando-a em sua composição, em seus procedimentos sintáticos de montagem, na voz, na gestualidade, no ritmo, trazendo novas possibilidades de atuação ao intérprete.

Um dos elementos sempre presentes que muito representa essa incorporação é o uso do microfone, que passa a ser parte constitutiva da performance, como um prolongamento do corpo e da voz do ator. Dessa maneira, em nenhum momento ele é escamoteado ou tratado como elemento externo, mas evidenciado. Ele passa a fazer parte da cena não só como elemento de amplificação de voz, mas como signo que evoca a autorrepresentação, poder, comando, um bastão de força para quem o empunha. "Se eu tô com o microfone, tá tudo no meu nome", é um "bordão" do rapper Rappin Hood 6 que sintetiza muito bem essa relação. Ainda assim, incorporado à performance, o microfone é um objeto que traz estranhamento, que interrompe a ação natural; seu uso, portanto, já traz consigo o distanciamento - elemento constitutivo do teatro épico. Além disso, o uso do microfone traz a necessidade de um novo comportamento corporal, pois como o som da voz é intermediado e sai das caixas amplificadas e não diretamente do corpo do ator, o foco de atenção do espectador se desloca no espaço, obrigando assim a uma expansão e dilatação do gesto, para que o público saiba em quem se referenciar, por exemplo, em uma cena musical onde várias pessoas estão com microfone. Portanto, durante sua performance, o ator-MC traz constantemente a veemência, o tônus urgente do MC. Ele está com o microfone e nesse momento deixa claro quem conduz a ação, dá o ponto de vista e ciceroneia o público.

Nesse contexto, o espetáculo Orfeu Mestiço, uma hip-hópera brasileira traz um personagem que resume esse espírito, o "MC-griot-corifeu”, narrador que permeia toda a encenação, alinhavando a trajetória, fazendo o papel do mestre de cerimônias no sentido estrito da palavra, como aquele que conduz, apresenta ou atua como microphone controller (um dos outros sentidos atribuídos ao acrônimo $\mathrm{MC}$ ), que de posse da palavra direciona a ação e o olhar do público, conduzindo a narrativa.

Na sua música de abertura em Orfeu Mestiço, uma hip-hópera brasileira, o texto de Claudia Schapira apresenta essa personagem, revelando a sua "carta de intenções":

${ }^{6}$ Sou Negrão. Rappin Hood. Sujeito Homem.Trama Records, 2005. 
"MC contadeiro falador

O que diz o que fala

Metrador

Trovadeiro explicadeiro orador

O que conta o que inventa explanador

Griot repentista assuntador

Transmisseiro boca-aberta

rhétoriqueur

O que fala o que emite apresentador

\section{Sou eu sou eu}

Boca ao mundo emissor

Romanceiro Trovador

Bocasom rimador

Bocaverso embolador

Resumideiro assuntadeiro linguador

Bocalíngua bocacanto glossador

Palavreiro narradeiro narrador

Palavreante argumenteiro relator

Vocalista menestrel recitador

Cantante cantadeiro enumerador

Poetrante instrumenteiro coplador

Quem recebe animadeiro zombador

Faladeiro poeta entoador

Sou eu sou eu

Poetrastro soador

Bisbilhoteiro explicador

Lírico prescruteiro

Língua ao mundo língua solta cantador"

Com essa apresentação e feito o "acordo" com o público, que aceita ser guiado por essa personagem, o MC-griot-corifeu começa a sua trajetória, e como se trata de um congá, vai servindo de interface para as diversas entidades que pairam no terreiro eletrônico. Ora dando voz a um guerrilheiro do Araguaia, ora se transformando em uma cangaceira do bando de Lampião, incorporando um Exú, ou um cantor da época dos grandes festivais; essa personagem vai dando voz aos discursos necessários para que a narrativa se desenrole. Também funciona como elemento "tensionador" e "destensionador" das cenas, imprimindo ritmo ou quebrando o estabelecido, e também como "comentarista", que traz muitas vezes de maneira crítica o discurso do próprio Núcleo Bartolomeu.

O processo criativo em que se deu a composição dessa personagem partiu de uma proposta da direção, e então, lançando mão de todo o arcabouço de repertórios levantados em três anos de pesquisa, foi-se dando um processo de colagem e de sampleamento de todas essas referências.

Um ponto fundamental na criação da personagem foi o trabalho vocal, numa procura pela entonação, pelo volume e pelo timbre, que evocaria a frequência ideal que 
corporificaria em diferentes nuances cada um dos arquétipos evocados pelo MC-griot-corifeu. As emissões vocais iam desde o canto lírico, passando pelo canto caboclo brasileiro, pelo fado, chegando até o rap, o afoxé ou as marchinhas de carnaval. Além disso, muito da rítmica, do comportamento corporal e vocal foi inspirado nos eventos de poetry slam, campeonatos de poesia performática que acontecem em todo o mundo, nos quais uma grande diversidade de poetas-performers participam com as mais variadas técnicas, vozes e gestos. Também houve um grande processo de musicalização do texto, já que se tratava de uma ópera e praticamente todas as falas eram cantadas. Esse processo se deu em parceria com a dramaturga e a direção musical, na mesma busca pela frequência que melhor expressasse o discurso da cena.

O depoimento e a autorrepresentação permearam todo o processo criativo dessa personagem, que por poder "entrar" e "sair" da fábula, interrompê-la ou fazê-la correr, contou com muita liberdade de estilos e brincou com planos e camadas de atuação.

$\mathrm{O}$ ator-MC encontra sua maturidade e com muita liberdade explora os diversos caminhos que essa linguagem pressupõe. A saga de Orfeu foi narrada e ainda há muito mais para se descobrir. Mas isso já é outra história que vem por aí.... 